\title{
EDITORIAL
}

\section{Entre polaridades e porosidades: aberturas plurais nas mídias}

RuMoRes, revista científica online dedicada aos estudos de comunicação, linguagem e mídias apresenta, em sua décima nona edição, um conjunto de textos que atravessam seus objetos para pensar as dinâmicas na cultura e os processos comunicacionais. Nas tensões e friç̧ões entre polaridades e porosidades, os artigos buscam descrever e analisar objetos originais e atuais a partir de seu movimento de circulação.

A primeira parte da edição é dedicada ao dossiê Polarizações, reunindo dez artigos selecionados a partir de seminário homônimo promovido pelo Grupo de Pesquisa Mídia e Narrativa, da Pontifícia Universidade Católica de Minas Gerais (PUC Minas), em Belo Horizonte. São textos que, de maneira geral, tentam observar as polarizações em que se fixam e se desdobram os discursos sobre a política e a cultura no país tentando atravessá-los a partir de suas manifestações midiáticas, pensando-os especialmente de forma crítica e de maneira dinâmica enquanto processo de circulação nas tramas da cultura e nas redes sociais. Como editor convidado para a seção Dossiê tivemos Márcio Serelle, coordenador do grupo de pesquisa Mídia e Narrativa (https://midiaenarrativa.wordpress.com/), que nos apresenta a proposta geral dos textos e também suas singularidades a partir dos eixos delineados em suas temáticas.

$\mathrm{Na}$ sequencia da edição, os artigos trazem temas livres que reafirmam a proposta da revista de analisar objetos a partir de suas implicações culturais e comunicacionais. Barbara Heller detecta em material jornalístico como está colocado o desejo e o desenho por liberdade de expressão, em "O mito da liberdade de expressão em cinco notícias". A possibilidade de expressão na mídia é representada através das aberturas dialógicas e intertextuais encontradas por Beatriz Braga Bezerra e Rogério Covaleski em "Pós-modernidade, entretenimento e consumo midiático: a narrativa intertextual Bad Blood". Por sua vez, o artigo "Diferenças imagéticas: considerações sobre a técnica e o símbolo no contexto comunicacional", de Eduardo Portanova Barros em coautoria com Anelise Angeli De Carli e Danilo Fantinel, acessa o desenho do social através do estudo das imagens, chegando à ideia de uma socialidade contemporânea.

Daniel Gambaro indaga sobre a forma de comunicação por meio da mídia sonora no texto "Como o jovem de São Paulo ouve rádio?", entendendo que uma abertura se deu com a assunção das redes sociais na dinâmica dos programas. 
Carolina Cavalcanti de Oliveira procura um modelo para essa abertura em vídeos publicados na rede ligados à culinária em "Dos modelos televisuais em vídeos na web: desdobramentos midiáticos do programa de receita culinária". A mídia impressa é retomada na tematização de uma ruptura em "Linguagem e ideologia no jornalismo de revistas: os discursos de Veja sobre as crises de 1999 e 2015", artigo de Mayara Luma Maia Lobato.

Encerramos a edição refletindo diretamente sobre a utilização ativa das possibilidades encontradas nas mídias digitais, feita sobretudo pelos jovens, publicando entrevista com o renomado pesquisador Henry Jenkins realizada por Fernanda Vasques Ferreira e Marcelli Alves à época em que o autor ainda desenvolvia a obra By any media necessary: the new youth activism (Por qualquer meio necessário: o novo ativismo jovem), editada recentemente pela editora da Universidade de Nova Iorque e ainda sem tradução em português.

De modo transversal, também em seus textos finais o tema das polarizações volta a ter lugar nos debates. Se as mídias apresentam lugar central na cultura contemporânea, cabe a nós, pesquisadores e estudiosos, empreender a análise crítica de seus discursos. É nessa visada que reunimos os artigos publicados na presente edição de RuMoRes, esperando que possam contribuir com aportes teóricos e adensar múltiplas perspectivas sobre a sociedade contemporânea.

Enquanto editores e editoras de revistas acadêmicas, sabemos o quanto nos desafia e também o quanto nos contenta poder disponibilizar, gratuitamente, conteúdos de qualidade em formato digital online. Não apenas do ponto de vista dos leitores e leitoras, que certamente se beneficiam com a circulação intensa de ideias nas mais diversas publicações, mas também do ponto de vista dos autores e autoras, que encontram espaços rigorosos e consolidados para exposição de suas investigações, o campo de estudos da Comunicação tem cumprido a contento, de diversas maneiras, os pilares de inovação e difusão integrantes da pesquisa científica. Aos editores e editoras de periódicos dedicamos este número de RuMoRes, esperando que possamos, cada vez mais, consolidar tradições e propor transformações em nossa atuação editorial e no aprimoramento dos modos de divulgação dos saberes produzidos nas universidades brasileiras. Aos diversos colaboradores e colaboradoras da revista, que trabalharam coletivamente nas várias etapas desta edição, nossos sinceros agradecimentos. 